\title{
Design and Performance of A Packer Fluid in $\mathrm{H}_{2} \mathrm{~S} / \mathrm{CO}_{2}$ Environments
}

\author{
Shuang Cheng ${ }^{1, a}$, Lei Wang ${ }^{2, b}$, Sheng-xiang Wang ${ }^{3, c}$, Ming-biao $\mathrm{Xu}^{4, \mathrm{~d} \text {, * }}$ \\ 1,2,3 CNOOC Iraq Limited, Beijing, 10010, P. R. China \\ ${ }^{4}$ Hubei Collaborative Innovation Center for Unconventional Oil and Gas, Yangtze University, \\ Jingzhou, 434023, P. R. China \\ achengshuang@cnoociraq.com, bwanglei@cnoociraq.com, ${ }^{\mathrm{c}}$ wangshx4@cnoociraq.com \\ ${ }^{d}$ xuhu_11@yeah.net ( ${ }^{*}$ Corresponding E-mail address),
}

Keywords: Packer fluid, Corrosion, Annulus, Corrosion inhibitor, Downhole environments

Abstract. Corrosion can remain a huge obstacle to the rehabilitation project of Missan Oilfields in Iraq, which is detected with high corrosive $\mathrm{H}_{2} \mathrm{~S} / \mathrm{CO}_{2}$ contents. To minimize corrosion risks in the annulus, a packer fluid has been set between the tubing and the casing above the production interval, and to fill the annulus. A series of tests have been carried out, on the basis of annulus conditions, to examine the performance of the designed packer fluid, including the corrosion resistance and the antibacterial capability. The component optimization test showed that under the considered conditions, an organic amine corrosion inhibitor exhibits effective corrosion inhibition than others, as well as the compatibility; in addition, the packer fluid has an excellent antibacterial property, and the growth rates of SRB and TGB can be controlled as low as 0 cells $/ \mathrm{ml}$, meeting the operation requirement on-site.

\section{Introduction}

Rehabilitation plan of Missan Oilfields is one of important strategies to maintain the stable production of oil \& gas. In existing production wells, however, corrosive downhole environments involving high $\mathrm{CO}_{2}$ partial pressure and a certain amount of $\mathrm{H}_{2} \mathrm{~S}$ have been inspected. For instance, distributions of corrosive gases, $\mathrm{CO}_{2}$ and $\mathrm{H}_{2} \mathrm{~S}$, are in the range of 3.4\% 6.8\% and $0.6 \% \sim 2.5 \%$, respectively. Besides, a large amount of ions such as $\mathrm{Na}^{+}, \mathrm{Ca}^{2+}, \mathrm{Mg}^{2+}$, and $\mathrm{Cl}^{-}$have been detected in formation water, and the salinity of produced water is as high as $235,858 \mathrm{ppm}$. These environmental factors can cooperatively reinforce the corrosiveness of fluid media, and then facilitate internal corrosion(i.e., casing and liner corrosion) ${ }^{[1 \sim 3]}$. In Missan Oilfields, production wells are all designed to install packers for avoiding internal corrosion in annulus. The standard practice for corrosion control in the annuli of packed wells is to complete the well by filling the annulus above the packer with an inhibited liquid packer fluid.

The packer fluid can provide a counter-pressure on the packer and assist in sealing the annulus against the inlet of the production fluid. Since a packer fluid remains in place until it is necessary to do remedial work on the well, which may not be for years, it has certain special requirements ${ }^{[4 \sim 6]}$ :

$\ddot{u}$ To be mechanically stable under downhole conditions, so that solids do not settle on the packer.

ü To be chemically stable and remain pumpable under bottomhole temperatures and pressures, such as high gel strengths, which would prevent the mud from being circulated, do not develop.

$\ddot{u}$ Contain materials that would seal any leaks that might develop.

$\ddot{u}$ Not to cause appreciable corrosion, and it must protect the metal surfaces from corrosion by formation fluids that might leak into the annulus. 
In the present work, a set of static coupon and antibacterial tests were implemented on the designed packer fluid to evaluate its corrosion and antibacterial properties. Coupons have the same ingredients as liner steels in the simulated formation water, and corrosion inhibitors were evaluated and screened using a dynamic coupon method. Meanwhile, influence of environmental factors on corrosion was systematically investigated. Furthermore, a composition analysis of corrosion production layer was conducted, which will be beneficial for exploring the corrosion mechanism of steels in the mixed $\mathrm{H}_{2} \mathrm{~S} / \mathrm{CO}_{2}$ environments.

\section{Experiments and methods}

Weight loss method Weight loss measurements are commonly used on exposure samples used to monitor corrosion rates in oil and gas production. It is a simple matter to convert these weight loss measurements into average depths of penetration. Uniform corrosion rate is calculated by the Eq 1:

$$
V_{\text {corr }}=A \frac{\Delta m}{\rho \cdot s \cdot t}
$$

wherein $A$ denotes to unit conversion factor, $\Delta m$ to weigh $\operatorname{loss}(\mathrm{g}), \rho$ to material density $\left(\mathrm{kg} / \mathrm{m}^{3}\right), s$ to surface area $\left(\mathrm{cm}^{2}\right)$, and $t$ to corrosion time(h). When $\mathrm{A}$ is $8.76 \times 10^{7}$, unit of corrosion rate is millimeter per year(mm/a).

Experimental apparatus Corrosion experiments were carried out in a special Hastelloy c276 autoclave(see Fig. 1), which is confirmed to be strong corrosion-resistant to wet $\mathrm{H}_{2} \mathrm{~S} / \mathrm{CO}_{2}$ gases. The test compartment consists of a vertically positioned tube with an inner diameter of $85 \mathrm{~mm}$ and a volume of 1 litre. The autoclave has a thermostatically controlled heating system and is certified for a pressure of maximum $10 \mathrm{MPa}$ at $250^{\circ} \mathrm{C}$.

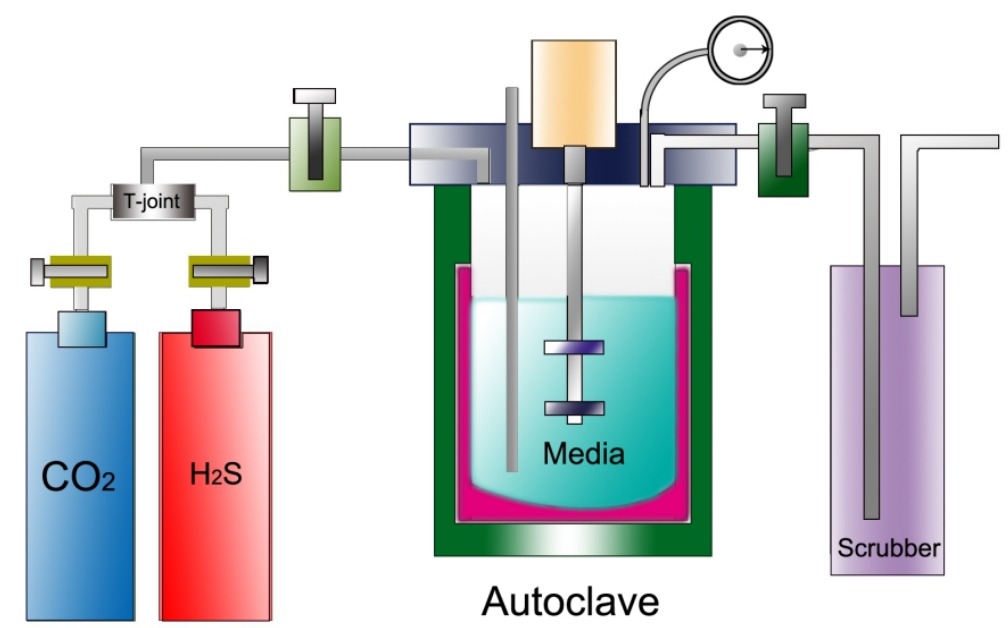

Fig.1 The instrument designed for $\mathrm{H}_{2} \mathrm{~S} / \mathrm{CO}_{2}$ corrosion tests

Experimental design The liner steel readily suffers from corrosion in harsh environments. Herein, $13 \mathrm{Cr}-180$ with a size of $50 \mathrm{~mm} \times 10 \mathrm{~mm} \times 2 \mathrm{~mm}$ has been typically used in dynamic corrosion tests. Several commercial corrosion inhibitors that exhibit strong inhibition against $\mathrm{H}_{2} \mathrm{~S} \mathrm{CO}_{2}$ corrosion(see Table 1) were preliminarily screened by means of comparing the corrosion rate. To the selected inhibitor, the injection amount was further optimized for reducing the corrosion rate to an acceptable level. 
Table 1 Description of the collected inhibitors

\begin{tabular}{|c|c|c|c|}
\hline No. & Sample & Main composition & Physical character \\
\hline 1 & LF & Organic amine & Puce liquid \\
\hline 2 & JJ-2 & Organic amine and imidazoline derivative & Puce liquid \\
\hline 3 & JCI-H2S & Amine-imidazoline derivative & Taupe liquid \\
\hline 4 & ZHEK & Organic amine & Yellow liquid \\
\hline 5 & JCI & Imidazoline derivative & Tan liquid \\
\hline
\end{tabular}

The corrosion media was prepared in terms of composition of formation water, and the slat contents of simulated formation water are listed in Table 2. Note that, Pure $\mathrm{N}_{2}$ was continuously bubbled into the simulated formation water for $0.5 \mathrm{~h}$ to expel the free oxygen before corrosion tests, and then corrosion tests were performed in the simulated formation water with or without corrosion inhibitors for $24 \mathrm{~h}$ under the related $\mathrm{H}_{2} \mathrm{~S} / \mathrm{CO}_{2}$ environments.

Table 2 Composition of the simulated formation water

\begin{tabular}{|c|c|c|c|c|c|c|}
\hline Salts & $\mathrm{NaCl}$ & $\mathrm{MgCl}_{2}$ & $\mathrm{CaCl}_{2}$ & $\mathrm{KBr}$ & $\mathrm{KCl}$ & $\mathrm{SrCl}_{2}$ \\
\hline Amount (wt.\%) & 14.5 & 0.6 & 3.3 & 0.09 & 0.14 & 0.1 \\
\hline
\end{tabular}

Corrosion tests To select a suitable inhibitor, static coupon tests are carried out at $90^{\circ} \mathrm{C}$ for $24 \mathrm{~h}$ in the $\mathrm{H}_{2} \mathrm{~S} / \mathrm{CO}_{2}$-saturated brine with a corrosion inhibitor amount of $50 \mathrm{ppm}$. In these cases several corrosion inhibitors evaluated previously, e.g., ZHEK, LF, JCI-H2S, and T03 series were typical examined.

Orthogonal tests of addition optimization Furthermore, Tests of Addition optimization was made. Several main chemical compositions involving sulfur and oxygen scavengers, corrosion inhibitor, $\mathrm{pH}$ control agent, and bactericide are used in the packer fluid. The additives of SS(sulfur scavenger), OS(oxygen scavenger), CI(corrosion inhibitor), and Bac(bactericide) have been investigated by orthogonal experiments, as shown in Table 3.

Table 3 Orthogonal experimental design for composition optimization

\begin{tabular}{|c|c|c|c|}
\hline \multirow{2}{*}{ Factor } & \multicolumn{3}{|c|}{ Levels } \\
\cline { 2 - 4 } & 1 & 2 & 3 \\
\hline Bac /wt.\% & 0 & 0.5 & 3.0 \\
\hline OS /wt.\% & 0 & 1.5 & 5 \\
\hline SS /wt.\% & 0 & 3 & 1600 \\
\hline CI /ppm & 0 & 400 & \\
\hline
\end{tabular}

Antibacterial tests With the defined compositions in tests presented above, antibacterial tests were designed here to investigate the antibacterial property for the packer fluid coupled with the annulus environments. Sulfate reducing bacteria(SRB) and metatrophic bacteria(TGB) were grown in defined packer fluid(with 0.5 wt. $\%$ bactericide) settled with $\mathrm{H}_{2} \mathrm{~S}$ and $\mathrm{CO}_{2}$ at $30^{\circ} \mathrm{C}, 60^{\circ} \mathrm{C}$, and $90^{\circ} \mathrm{C}$, respectively, to determine concentration of bacteria and kill effects from the cell. All testing steps followed "SY/T 5329-2012" and "SY/T6397-1997".

\section{Results and discussion}

Composition analysis of packer fluid The packer fluid can be obtained by adding a series of functional additives such as weighting agent, OS, SS, CI, pH control agent, and Bac in the pure brine. Inorganic salts such as $\mathrm{NaCl}, \mathrm{KCl}, \mathrm{HCOONa}, \mathrm{HCOOK}, \mathrm{ZnBr}$, etc., are generally applied, with which the packer fluid density can be controlled in the range of $1.00 \sim 1.80$ s.g. In the $\mathrm{H}_{2} \mathrm{~S} / \mathrm{CO}_{2}$ environment, $\mathrm{CI}$ is inevitable and should be firstly considered for retarding inner corrosion damage 
to well profiles. The additives of OS and SS are designed to further introduce to eliminate oxygen and sulfur. As a result of incursion of OS and SS, the corrosion damage can also be reduced.

Selection of corrosion inhibitor Corrosion inhibitors, LF, ZHEK, T03 series, and JCI-H2S, that were confirmed good corrosion inhibition in previous tests, were further examined and evaluated in the saturated brine to select the appropriate inhibitors. All tests were typically carried out on N80 steel at $90^{\circ} \mathrm{C}$ for $24 \mathrm{~h}$, in the saturated brine with an inhibitor amount of 50ppm, and corrosion rates were examined. The testing resulted is schematically presented in Figure 2.

Figure 2 shows that corrosion rates low as adding the corrosion inhibitors. In the aspect of steel grades, P110 and C75 steels exhibit better corrosion inhibition than N80 and C95 in the saturated brine, while N80 appears to be much effective decline with an addition of the corrosion inhibitors. In the aspect of inhibition, LF and ZHEK provide excellent inhibition results, through which corrosion rates are reduced to $0.03 \mathrm{~mm} / \mathrm{a}$ and $0.02 \mathrm{~mm} / \mathrm{a}$, respectively. Undoubtedly, these two inhibitors can be utilized in packer fluids. However, ZHEK has bad compatibility with the high salinity of brine. The higher the amount of LF in brines, the worse the compatibility can be. Therefore, ZHEK is proposed to use as the corrosion inhibitor in packer fluids.

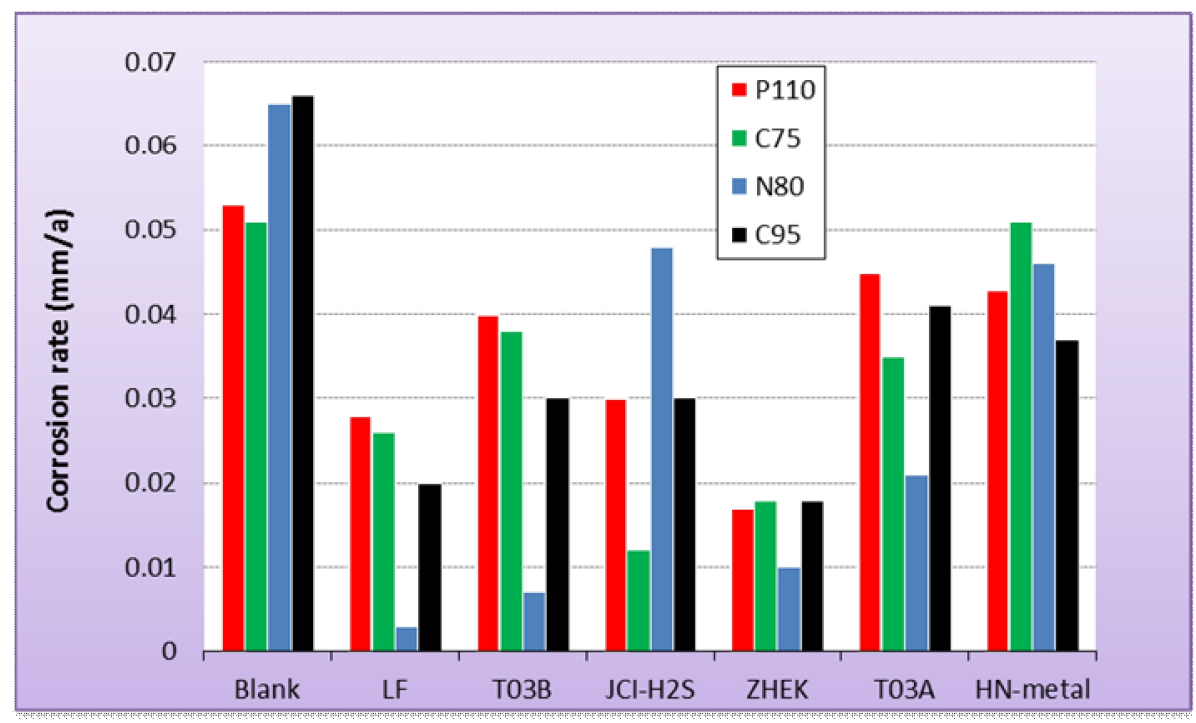

Fig. 2 Comparison of corrosion rate for the six inhibitors in the saturated brine

Component optimization The additions of several key components, e.g., Bac, OS, SS, and CI were concerned by a set of orthogonal experiments. All tests were typically carried out on N80 steel at $95^{\circ} \mathrm{C}$ for $24 \mathrm{~h}$. The corrosive media was prepared with the corresponding brine saturated with $\mathrm{H}_{2} \mathrm{~S}$ and $\mathrm{CO}_{2}$. Experiment conditions and relative results are collected in Table 4. 
Table 4 Orthogonal experimental results of optimizing compositions of the packer fluid

\begin{tabular}{|c|c|c|c|c|c|}
\hline Factors & $\mathrm{Bac}$ & OS & SS & CI & $\begin{array}{c}\text { Corrosion rate } \\
(\mathrm{mm} / \mathrm{a})\end{array}$ \\
\hline Experiment 1 & 1 & 1 & 1 & 1 & 0.147 \\
\hline Experiment 2 & 1 & 2 & 2 & 2 & 0.031 \\
\hline Experiment 3 & 1 & 3 & 3 & 3 & 0.017 \\
\hline Experiment 4 & 2 & 1 & 2 & 3 & 0.014 \\
\hline Experiment 5 & 2 & 2 & 3 & 1 & 0.034 \\
\hline Experiment 6 & 2 & 3 & 1 & 2 & 0.009 \\
\hline Experiment 7 & 3 & 1 & 3 & 2 & 0.014 \\
\hline Experiment 8 & 3 & 2 & 1 & 3 & 0.009 \\
\hline Experiment 9 & 3 & 3 & 2 & 1 & 0.024 \\
\hline Mean value 1 & 0.065 & 0.058 & 0.055 & 0.068 & \\
\hline Mean value 2 & 0.019 & 0.025 & 0.023 & 0.018 & \\
\hline Mean value 3 & 0.016 & 0.017 & 0.022 & 0.013 & \\
\hline Range & 0.049 & 0.041 & 0.033 & 0.055 & \\
\hline
\end{tabular}

In terms of range of variance analyses, it is determined that factors influencing the corrosion rate of N80 steel in considered system are fairly different. The range values of four factors, Bac, OS, SS, and CI, are $0.049,0.041,0.033$, and 0.055 , respectively. They can influence the corrosion process in an order of $\mathrm{CI}>\mathrm{Bac}>\mathrm{OS}>\mathrm{SS}$. It is obvious that for the additives referred here, CI causes the strongest effect on corrosion rates. In addition, Bac exhibits effective corrosion inhibition in packer fluids. Meanwhile, one can be found that the lowest corrosion rate occurs at the condition of Bac3-OS3-SS3-CI3. As a result of orthogonal tests, CI and Bac should be firstly considered for the comprehensive performance.

Furthermore, influence of four components on corrosion rate is given in Figure 3. One can readily find in Figure 3 that all factors give similar corrosion process: corrosion rates will decline with an increment of additions. It can be reasonably concluded that four additives all possess inhibition. On the other hand, one can also observe that at the initial stage, corrosion rates rigorously reduce with addition of additives; after that, this decline trend will mitigate with more addition of additives. It should be noted that, the density of packer fluid can be adjusted by varying amount of HCOONa in the range of $1.12 \sim 1.3 \mathrm{~g} / \mathrm{cm}^{3}$ to meet downhole pressure. At the same time, $0.2 \% \mathrm{pH}$-adjusting agent is introduced to adjust $\mathrm{pH}$ value of packer fluid at 8 . Taking into account of additive functions, compatibility, and inhibition, addition of corrosion inhibitor, LF and ZHEK, is recommended to be $400 \mathrm{ppm}$, and the bactericide is to be $0.5 \mathrm{wt} . \%$, which will be applied in the later antimicrobial experiments. Meanwhile, OS and SS are proposed to be $0.5 \mathrm{wt} \%$ and $0.5 \mathrm{wt} . \%$, respectively, in conjunction with previous results. That is to say the components of packer fluid can be designed as follows:

$\mathrm{NaCl}$ solution $+400 \mathrm{ppmCI}+0.5 \% \mathrm{Bac}+0.5 \% \mathrm{OS}+0.5 \% \mathrm{SS}+0.2 \% \mathrm{pH}$-adjusting agent + density-adjusting agent 


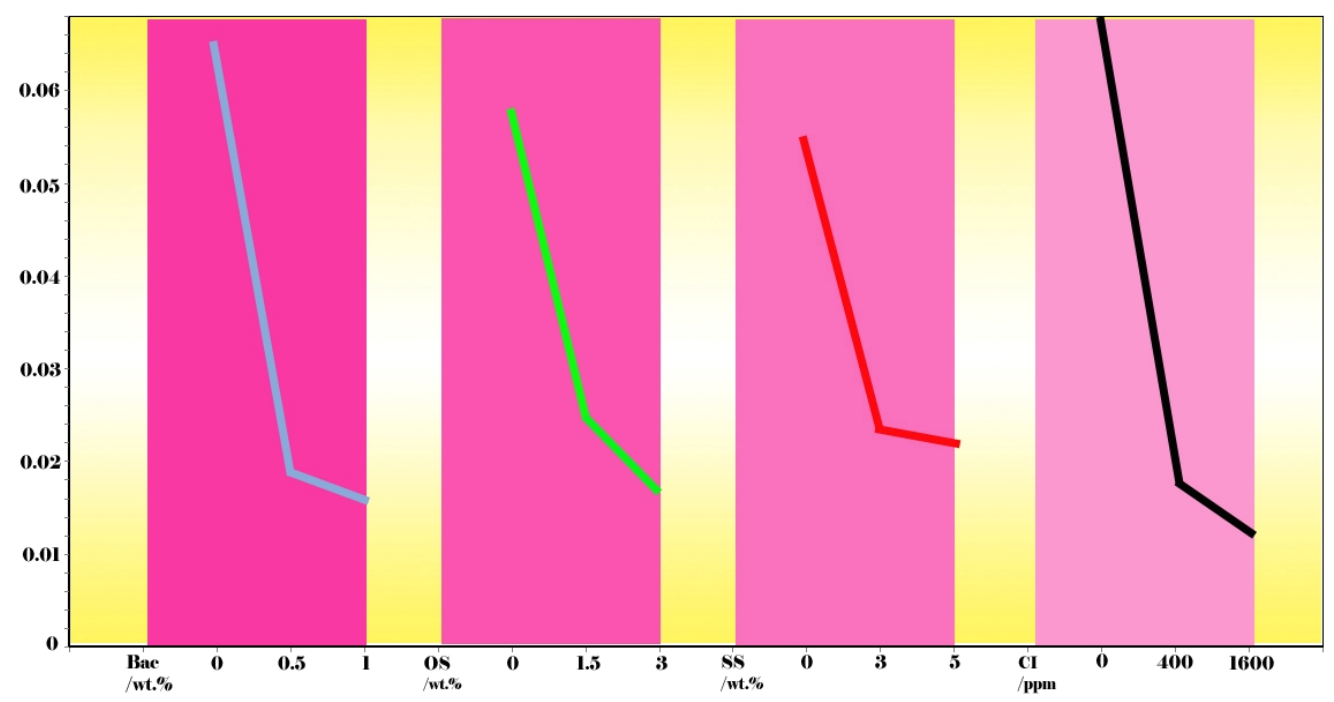

Fig. 3 Influence of four factors on corrosion rate

Antimicrobial property Antimicrobial property is, in addition to corrosion inhibition, another key property for packer fluid, while taking account into $\mathrm{H}_{2} \mathrm{~S}$-rich, aerobic or anaerobic environments. Two kinds of bacteria, SRB and TGB, are commonly found in such conditions. The antimicrobial capacity of packer fluid defined here examined in terms of downhole environment. Bottles were incubated at $30^{\circ} \mathrm{C}, 60^{\circ} \mathrm{C}$, and $90^{\circ} \mathrm{C}$ to quantify microbial growth. Bacterial concentrations were calculated using the MPN method. The testing results are listed in Table 5.

Table 5 Antibacterial testing results

\begin{tabular}{|c|c|c|c|}
\hline \multirow{2}{*}{ NO. } & \multirow{2}{*}{ Temp. $\left({ }^{\circ} \mathrm{C}\right)$} & \multicolumn{2}{|c|}{ Log of bacterial cells/ml } \\
\cline { 3 - 4 } & 30 & SRB & TGB \\
\hline 1 & 60 & 0 & 0 \\
\hline 2 & 90 & 0 & 0 \\
\hline 3 & 0 & 0 \\
\hline
\end{tabular}

The results show that in the considered temperature range, the defined packer fluid is quite effective against SRB and TGB. The growth rates of SRB and TGB are both as low as 0 cells/ml, suggesting the packer fluid system can entirely inhibit the SRB and TGB growth in treated cultures. These results indicate excellent antibacterial property for the defined packer fluid.

\section{Conclusions}

To ensure continuous, safe, and economic operations in Missan Oilfields, we designed a specific packer fluid in terms of on-site conditions. Two key properties of packer fluid, corrosion and antibacterial capability, have been evaluated. The main conclusions are listed as follows:

(1) Organic amine, LF, is confirmed with excellent corrosion inhibition and is selected as the primary corrosion inhibitor(CI).

(2) The ingredient of packer fluid is optimized as:

$\mathrm{NaCl}$ solution $+400 \mathrm{ppmCI}+0.5 \% \mathrm{Bac}+0.5 \% \mathrm{OS}+0.5 \% \mathrm{SS}+0.2 \% \mathrm{pH}$-adjusting agent + density-adjusting agent, and the main components can vary the corrosion process in an order of $\mathrm{CI}>\mathrm{Bac}>\mathrm{OS}>\mathrm{SS}$.

(3) The packer fluid has excellent antimicrobial property, and the microbial growth can be entirely inhibited, especially fort SRB and TGB.

The designed packer fluid will be useful for control of internal annual corrosion in wet $\mathrm{H}_{2} \mathrm{~S} / \mathrm{CO}_{2}$ environments, and it also will provide technological and theoretical supports for rehabilitation of 
Missan Oilfields.

\section{Acknowledgements}

We are grateful to CNOOC Iraq Co., Ltd. (Project No. CMITWRS-210-PRT-10.30-20040) for financial support and allowable publication.

\section{References}

[1] S. Papavniasam, R. W. Revie, and M. Bartos. Testing methods and standards for oil field corrosion inhibitors. NACE 04424 (2004).

[2] R. Hampson, C. Moir, T. Freeney. Working With Coiled Tubing in $\mathrm{H}_{2} \mathrm{~S}$ and $\mathrm{CO}_{2}$ Wells: A Global Perspective, SPE 121294 (2009).

[3] B. Kermani, J. Martin, K. Esaklul. Materials Design Strategy: Effects of $\mathrm{H}_{2} \mathrm{~S} / \mathrm{CO}_{2}$ Corrosion on Materials Selection, Corrosion, Paper No.06121 (2006).

[4] E. A. Moustafa, M. J. James, E. Ryan, et al. High-Performance Water-Based Insulating Packer Fluids. SPE 109130 (2007)

[5] M. J. Sanborn, T. Enrico, B. Nam, et al. The Role of Packer Fluids in the Annular Environmentally Assisted Cracking of CRA Production Tubing, SPE 114131 (2008)

[6] E. Ryan, F. E. Scott, R.Edward, et al. High Performance Aqueous Insulating Packer Fluid Improved Flow Assurance and Reduced Annular Pressure Buildup in Ultra Deepwater Wells, SPE 135117 (2010). 